Jurnal Manajemen dan Bisnis, Volume 3, No. 1, Juli 2021

\title{
PENTINGNYA HUKUM PERLINDUNGAN KONSUMEN DALAM JUAL BELI
}

\author{
Puteri Asyifa Octavia Apandy ${ }^{1}$, Melawati ${ }^{2}$, Panji Adam ${ }^{3}$ \\ Fakultas Syariah Universitas Islam Bandung
}

\begin{abstract}
Buying and selling is a familiar thing in the life of Indonesian people, every day there are people who carry out buying and selling activities. Buying and selling can be interpreted as a transaction carried out by two parties, namely the seller as a business actor and the buyer as a consumer. In buying and selling activities, sometimes one of the parties is disadvantaged, especially the consumer. Because of this, a consumer protection law was issued in Indonesia. Not a few Indonesian people do not know the importance of consumer protection law, especially for buying and selling activities. Based on this, the authors conducted research to find out why consumer protection laws are important to be understood by sellers as business actors and buyers as consumers. This article will discuss the importance of consumer protection laws in buying and selling. Starting from the definition of buying and selling, understanding consumer protection law, the importance of consumer protection law for sellers and the importance of consumer protection law for buyers. This research uses descriptive method (describes) analysis (outlines). This article concludes that consumer protection law is very important in buying and selling activities, for the seller as an important business actor because it can prevent doing things that are prohibited by law as well as things that are harmful, for the buyer as a consumer it is important because it can guarantee security when carrying out buying and selling activities.
\end{abstract}

Keywords: Consumer protection law, seller, buyer

\begin{abstract}
ABSTRAK
Jual beli merupakan hal yang tidak asing lagi di kehidupan masyarakat Indonesia, setiap harinya pasti ada orang yang melakukan kegiatan jual beli. Jual beli dapat diartikan sebagai sebuah transaksi yang dilakukan oleh dua pihak yaitu pihak penjual sebagai pelaku usaha dan pihak pembeli sebagai konsumen. Didalam kegiatan jual beli terkadang salah satu pihak ada yang dirugikan, terutamanya pihak konsumen. Karena hal tersebut di Indonesia dikeluarkan hukum perlindungan konsumen. Tidak sedikit masyarakat indonesia yang belum tahu apa pentingnya hukum perlindungan konsumen, terutamanya untuk kegiatan jual beli. Berdasarkan hal tersebut maka penulis melakukan penelitian untuk mengetahui mengapa hukum perlindungan konsumen penting untuk dipahami oleh pihak penjual selaku pelaku usaha dan pembeli selaku konsumen. Artikel ini akan membahas tentang pentingnya hukum perlindungan konsumen dalam jual beli. Mulai dari pengertian jual beli, pengertian hukum perlindungan konsumen, pentingnya hukum perlindungan konsumen bagi penjual dan pertingnya hukum perlindungan konsumen bagi pembeli. Penelitian ini menggunakan metode deskriptif (menggambarkan) analisis (menguraikan). Artikel ini menyimpulkan bahwa hukum perlindungan konsumen sangatlah penting dalam kegiatan jual beli, bagi pihak penjual selaku pelaku usaha penting karena dapat mencegah melakukan hal yang dilarang dalam hukum serta hal yang merugikan, bagi pihak pembeli selaku konsumen penting karena dapat menjamin keamanan ketika melakukan kegiatan jual beli.
\end{abstract}

Kata-kata Kunci: Hukum perlindungan konsumen, penjual, pembeli

Korespondensi: Puteri Asyifa Octavia Apandy ${ }^{1}$, Melawati ${ }^{2}$, Dosen Pengampu: Panji Adam, S.Sy., M.H. ${ }^{3}$. Universitas Islam Bandung. Jl. Tamansari, No. 1, Bandung, Jawa Barat, Indonesia. Kode Pos: 40116. Email: puteriasyifaocta@gmail.com ${ }^{1}$, melapow15@gmail.com ${ }^{2}$,panjiadam06@gmail.com ${ }^{3}$ 
Jurnal Manajemen dan Bisnis, Volume 3, No. 1, Juli 2021

\section{PENDAHULUAN}

Jual beli merupakan hal yang tidak asing lagi di kehidupan masyarakat Indonesia, setiap harinya pasti ada orang yang melakukan kegiatan jual beli. Jual beli dapat diartikan sebagai sebuah transaksi yang dilakukan oleh dua pihak yaitu pihak penjual sebagai pelaku usaha dan pihak pembeli sebagai konsumen.

Didalam kegiatan jual beli terkadang salah satu pihak ada yang dirugikan, terutamanya pihak konsumen. Contohnya pihak konsumen dirugikan karena penjual selaku pelaku usaha dalam melakukan penjualan barangnya tidak jujur dan juga menipu. Karena hal tersebut di Indonesia dikeluarkanlah hukum yang mengatur tentang perlindungan konsumen. Tidak sedikit masyarakat indonesia yang belum tahu apa saja pentingnya hukum perlindungan konsumen, terutamanya untuk kegiatan jual beli.

Berdasarkan hal tersebut maka penulis melakukan penelitian untuk mengetahui mengapa hukum perlindungan konsumen penting untuk dipahami oleh pihak penjual selaku pelaku usaha dan pembeli selaku konsumen. Sehingga kita dapat mengetahui seberapa pentingnya memahami hukum perlindungan konsumen, dan juga dapat menjadi sumber ilmu pengetahuan yang bermanfaat.

Artikel ini akan membahas tentang pentingnya hukum perlindungan konsumen dalam jual beli. Mulai dari pengertian jual beli, pengertian hukum perlindungan konsumen, pentingnya hukum perlindungan konsumen bagi penjual dan pertingnya hukum perlindungan konsumen bagi pembeli.

\section{KAJIAN PUSTAKA}

Pembahasan mengenai pentingnya hukum perlindungan konsumen dalam jual beli ini dimulai dengan mempelajari sumber buku-buku, jurnal dan website internet. Penulis menggunakan 3 (tiga) sumber buku, 1 (satu) sumber jurnal dan 4 (empat) sumber website yang masing-masing membahas terkait materi yang akan dibahas oleh penulis. Salah satu rincian sumbernya sebagai berikut:

1. Pertama, buku oleh Prof. Dr. Neni Sri Imaniyati, SH., M.H. dan Panji Adam Agus Putra, S.Sy., M.H. yang berjudul "Hukum Bisnis: Dilengkapi Dengan Kajian Hukum Bisnis Syariah", buku ini menguraikan beberapa masalah yang berkaitan dengan hukum bisnis, meliputi kelembagaan, kegiatan usaha, dan proses untuk melaksanakan kegiatan usaha tersebut.

2. Kedua, jurnal yang bersumber dari website Badan Standardisasi Nasional. Didalamnya terdapat Undang-undang No. 8 Tahun 1999 Perlindungan Konsumen yang lengkap.

3. Ketiga, website oleh Sitti Saroh yang berjudul "Manfaat Perlindungan Konsumen", website ini membahas dan menjelaskan manfaat-manfaat dari perlindungan konsumen.. 


\section{Jurnal Manajemen dan Bisnis, Volume 3, No. 1, Juli 2021}

Beberapa sumber buku, jurnal dan website yang lainnya pun semuanya bersangkutan dengan artikel yang akan dibahas oleh penulis.

\section{METODE}

Penelitian ini bersifat deskriftif (menggambarkan), analisis (menguraikan). Setelah data terkumpul sedemikian, diolah sehingga menjadi terarah dan sistematis, mulai menuliskan data-data yang berkaitan dengan tema pembahasan, mengedit, mengklarifikasi, mereduksi dan menyajikan.

\section{HASIL DAN PEMBAHASAN}

\section{A. Jual Beli}

Kegiatan jual beli dapat diartikan sebagai salah satu transaksi tukar-menukar barang yang mempunyai nilai, yang dimana salah satu pihak (penjual) menjual barang tersebut, dan pihak lain (pembeli) membeli barangnya sesuai dengan kesepakatan. Singkatnya jual beli adalah transaksi antara penjual (pelaku usaha) dan pembeli (konsumen).

Didalam kesepakatan jual beli terdapat dua pihak yaitu pihak penjual dan pihak pembeli. Penjual adalah seseorang yang menjual barang atau jasanya ke konsumen/ pembeli. Sedangkan pembeli adalah seseorang yang membeli barang tertentu atau menggunakan jasa tertentu dan disebut dengan konsumen.

Dalam kegiatan jual beli tidak selamanya berjalan dengan baik, pasti ada beberapa orang yang jahat dan merugikan salah satu pihak dalam jual beli. Maka dari itu diperlukannya sebuah hukum yang dapat mengatur jalannya sebuah transaksi jual beli, sehingga tidak ada pihak yang akan dirugikan.

Jual Beli dalam ajaran agama Islam sendiri hukumnya adalah halal, hal tersebut tercantum dalam Firman Allah Q.S Al-Baqarah ayat 275 :

$$
\text { وَأَحَلَّ اللَّهُ الْبَيْعَ وَحَرَّمَ الرِّبَا }
$$

Terjemah: "Dan Allah telah menghalalkan jual beli dan mengharamkan riba.".

Jual beli yang dibenarkan dalam Islam adalah jual beli yang seluruh rukun dan syarat jual belinya terpenuhi, atau bisa dikatakan jual belinya sesuai dengan hukum syariat Islam. Sama halnya dengan masyarakat yang melakukan jual beli di Negara Indonesia, terdapat juga hukum yang mengatur yang menyangkut jual beli, salah satunya hukum perlindungan konsumen.

\section{B. Hukum Perlindungan Konsumen}

Hukum perlindungan konsumen merupakan hukum yang memuat asas-asas kaidah-kaidah yang bersifat mengatur dan juga mengandung sifat yang melindungi kepentingan konsumen, hukum perlindungan konsumen juga menjadi salah satu aspek yang menciptakan rasa aman dan nyaman dalam kegiatan jual beli.

Hukum perlindungan konsumen adalah keseluruhan asas-asas dan kaidah yang mengatur dan melindungi konsumen dalam 
Jurnal Manajemen dan Bisnis, Volume 3, No. 1, Juli 2021

hubungan dan masalah penyediaan dan penggunaan produk konsumen antara penyedia dan penggunaanya dalam bermasyarakat. Penyedia produk konsumen bisa disebut dengan penjual dan pengguna produk konsumen tersebut bisa disebut dengan pembeli.

Ada juga yang berpendapat, hukum perlindungan konsumen merupakan bagian dari hukum konsumen yang lebih luas itu. "Az. Nasution, berpendapat bahwa hukum konsumen yang memuat asas-asas atau kaidahkaidah bersifat mengatur, dan juga mengandung sifat yang melindungi kepentingan konsumen.”.

Dengan demikian hukum perlindungan konsumen atau hukum konsumen itu dapat diartikan sebagai keseluruhan peraturanperaturan hukum yang mengatur hak-hak dan kewajiban-kewajiban konsumen dan produsen yang timbul dalam usahanya untuk memenuhi kebutuhannya.

Berdasarkan pengertian-pengertian mengenai hukum perlindungan konsumen dapat sangat menentukan perlindungan hukum terhadap para konsumen. Karena semakin luasnya pengertian istilah tertentu yang terdapat dalam hukum perlindungan konsumen akan semakin besar kemungkinan bagi konsumen untuk mendapatkan perlindungan hukum dan rasa aman.

Pemerintah Republik Indonesia pada tanggal 20 April 1999 telah mengesahkan
Undang-Undang Nomor 8 Tahun 1999 tentang Perlindungan Konsumen. Undang-Undang Perlindungan Konsumen harus memberikan manfaat yang sebesar-besarnya kepada kedua pihak, konsumen dan pelaku usaha (misalnya penjual dan pembeli), sehingga tidak ada satu pihak yang kedudukannya lebih tinggi dibanding pihak lainnya.

\section{Pentingnya Hukum Perlindungan Konsumen Bagi Penjual}

Meskipun ditujukan untuk melindungi kepentingan konsumen, Undang-Undang Perlindungan Konsumen tidak bertujuan untuk mematikan pelaku usaha. Dengan adanya Undang-Undang Perlindungan Konsumen, pelaku usaha diharapkan lebih termotivasi untuk meningkatkan daya saingnya dengan memperhatikan kepentingan konsumen.

Hukum perlindungan konsumen sangatlah penting bagi pihak penjual selaku pelaku usaha, karena dapat mencegah penjual melakukan hal-hal yang dilarang dalam hukum dan juga dapat mencegah ruginya pihak pembeli selaku konsumen. Apabila penjual memahami hukum perlindungan konsumen maka mereka tidak akan melanggar hukum tersebut dan berjualan sesuai dengan aturan yang telah ditetapkan.

Berikut salah satu contoh isi undangundang yang perlu penjual selaku pelaku usaha pahami agar nantinya tidak melakukan hal yang dilanggar dan merugikan pembeli selaku konsumen. Contohnya yaitu asas-asas 
Jurnal Manajemen dan Bisnis, Volume 3, No. 1, Juli 2021

perlindungan konsumen yang diatur dalam Pasal 2 Undang-undang Nomor 8 Tahun 1999 tentang Perlindungan Konsumen, beserta penjelasan asas-asas nya sebagai berikut:

1. Asas Manfaat

Konsumen maupun pelaku usaha atau produsen berhak memperoleh manfaat yang diberikan. Tidak boleh bersifat salah satu dari kedua belah pihak, sehingga tidak ada salah satu pihak yang merasakan manfaat ataupun kerugian.

2. Asas Keadilan

Konsumen dan produsen/pelaku usaha dapat berlaku adil dengan perolehan hak dan kewajiban secara seimbang atau merata.

\section{Asas Keseimbangan}

Sebuah keseimbangan antara hak dan kewajiban para produsen dan konsumen dengan mengacu pada peraturan hukum perlindungan konsumen.

\section{Asas Keamanan dan Keselamatan}

Sebuah jaminan hukum bahwa konsumen akan memperoleh manfaat dari produk yang dikonsumsi/dipakainya dan sebaliknya bahwa produk itu tidak akan mengganggu keselamatan jiwa dan harta bendanya.

\section{Asas Kepastian Hukum}

Sebuah pemberian kepastian hukum bagi produsen maupun konsumen dalam mematuhi dan menjalankan peraturan hukum dengan apa yang menjadi hak dan kewajibannya. Hal ini dilakukan tanpa membebankan tanggung jawab kepada salah satu pihak, serta negara menjamin kepastian hukum.

\section{Pentingnya Hukum Perlindungan Konsumen Bagi Pembeli}

Hukum perlindungan konsumen bagi pembeli adalah hal yang sangat penting atau utama dalam kegiatan transaksi jual beli, karena dapat menghasilkan keamanan dan mencegah terjadinya kerugian-kerugian bagi pihak pembeli selaku konsumen. Dengan adanya hukum ini juga pembeli mendapatkan hak barang yang sesuai dengan pemberitahuan sebelumnya atau barang yang sesuai dengan yang dijanjikan oleh pihak penjual selaku pelaku usaha.

Pembeli selaku konsumen serta penjual selaku pelaku usaha berhak untuk menerima manfaat yang bersifat tidak merugikan salah satu pihak. Keterbukaan informasi juga menjadi tolak ukur utama yang dilakukan pelaku usaha terhadap konsumen, guna mendapat kepercayaan maupun kenyaman terhadap konsumen sebagai pengguna barang atau produk yang dibeli.

Berikut dua contoh isi undang-undang yang perlu pembeli selaku konsumen pahami agar nantinya dapat menghasilkan rasa aman dan kepercayaan ketika akan membeli suatu barang ataupun jasa. Contoh pertama yaitu tujuan hukum perlindungan konsumen yang diatur dalam Pasal 3 Undang-undang Nomor 8 Tahun 1999 tentang Perlindungan Konsumen sebagai berikut: 
Jurnal Manajemen dan Bisnis, Volume 3, No. 1, Juli 2021

1. Meningkatkan kesadaran, kemampuan dan kemandirian konsumen untuk melindungi diri;

2. Mengangkat harkat dan martabat konsumen dengan cara menghindarkannya dari ekses negatif pemakaian barang dan/atau jasa;

3. Meningkatkan pemberdayaan konsumen dalam memilih, menentukan, dan menuntut hak-haknya sebagai konsumen;

4. Menciptakan sistem perlindungan konsumen yang mengandung unsur kepastian hukum dan keterbukaan informasi serta akses untuk mendapatkan informasi;

5. Menumbuhkan kesadaran pelaku usaha mengenai pentingnya perlindungan konsumen sehingga tumbuh sikap yang jujur dan bertanggungjawab dalam berusaha;

6. Meningkatkan kualitas barang dan/atau jasa yang menjamin kelangsungan usaha produksi barang dan/atau jasa, kesehatan, kenyamanan, keamanan, dan keselamatan konsumen.

Contoh kedua yaitu hak-hak konsumen yang diatur dalam Pasal 4 Undang-undang Nomor 8 Tahun 1999 tentang Perlindungan Konsumen sebagai berikut:

1. Hak atas kenyamanan, keamanan, dan keselamatan dalam mengkonsumsi barang dan/atau jasa;
2. Hak untuk memilih barang dan/atau jasa serta mendapatkan barang dan/atau jasa tersebut sesuai dengan nilai tukar dan kondisi serta jaminan yang dijanjikan;

3. Hak atas informasi yang benar, jelas, dan jujur mengenai kondisi dan jaminan barang dan/atau jasa;

4. Hak untuk didengar pendapat dan keluhannya atas barang dan/atau jasa yang digunakan;

5. Hak untuk mendapatkan advokasi, perlindungan, dan upaya penyelesaian sengketa perlindungan konsumen secara patut;

6. Hak untuk mendapat pembinaan dan pendidikan konsumen;

7. Hak untuk diperlakukan atau dilayani secara benar dan jujur serta tidak diskriminatif;

8. Hak untuk mendapatkan kompensasi, ganti rugi dan/atau penggantian, apabila barang dan/atau jasa yang diterima tidak sesuai dengan perjanjian atau tidak sebagaimana mestinya;

9. Hak-hak yang diatur dalam ketentuan peraturan perundang-undangan lainnya.

\section{KESIMPULAN}

Singkatnya jual beli adalah transaksi antara penjual dan pembeli. Didalam kesepakatan jual beli terdapat dua pihak yaitu pihak penjual dan pihak pembeli. Penjual adalah seseorang yang menjual barang atau jasanya ke 
Jurnal Manajemen dan Bisnis, Volume 3, No. 1, Juli 2021

konsumen/ pembeli. Sedangkan pembeli adalah seseorang yang membeli barang tertentu atau menggunakan jasa tertentu dan disebut dengan konsumen.

Di Negara Indonesia, terdapat hukum yang menyangkut dengan jual beli, salah satunya hukum perlindungan konsumen. Hukum perlindungan konsumen atau hukum konsumen itu dapat diartikan sebagai keseluruhan peraturan-peraturan hukum yang mengatur hakhak dan kewajiban-kewajiban konsumen dan produsen yang timbul dalam usahanya untuk memenuhi kebutuhannya.

Hukum perlindungan konsumen sangatlah penting bagi pihak penjual selaku pelaku usaha, karena dapat mencegah penjual melakukan halhal yang dilarang dalam hukum dan juga dapat mencegah ruginya pihak pembeli yaitu selaku konsumen. Apabila penjual memahami hukum perlindungan konsumen maka mereka tidak akan melanggar hukum tersebut dan berjualan sesuai dengan aturan yang telah ditetapkan.

Hukum perlindungan konsumen bagi pembeli juga adalah hal yang sangat penting atau utama dalam kegiatan transaksi jual beli, karena dapat menghasilkan keamanan dan mencegah terjadinya kerugian-kerugian bagi pihak pembeli selaku konsumen. Dengan adanya hukum ini juga pembeli mendapatkan hak barang yang sesuai dengan pemberitahuan sebelumnya atau barang yang sesuai dengan yang dijanjikan oleh pihak penjual selaku pelaku usaha.

\section{DAFTAR PUSTAKA}

Ayu, L. (2018, Mei 9). Pemahaman Mengenai Jual Beli Secara Singkat. Diambil kembali dari Kompasiana:

https://www.kompasiana.com/real_ss/5af31da 1bde57542d975c664/pemahaman-mengenaijual-beli-secarasingkat $\% 20$ Hukum $\% 20$ Perlindungan $\% 20$ Kons umen $\% 20 \mathrm{di} \% 20$ Indonesia\%20\%20Jurnal\%20Hukum

DSLA. (t.thn.). Perlindungan Konsumen aman Oleh UU Perlindungan Konsumen. Diambil kembali dari DSLAlawfirm: https://www.dslalawfirm.com/id/perlindungankonsumen/

Kristiyanti, C. T. (2011). Hukum Perlindungan Konsumen. Jakarta: Sinar Grafika.

Kurniawan. (2011). Hukum Perlindungan Konsumen: Problematika kedudukan dan Kekuatan Putusan badan Penyelesaian Sengketa Konsumen (BPSK). Malang: Universitas Brawijaya Press.

Nuryana, Y. (2003). Korelasi Fawatih Al-Suwar Dan Khawatim Al-Suwar Dalam Al-Qur'an. Tafsir Hadis.

Saroh, S. (2021, Mei 9). Manfaat Perlindungan Konsumen. Diambil kembali dari Academia.edu:

https://www.academia.edu/19282313/Manfaat _Perlindungan_Konsumen_adalah

Sri, N., \& Putra, P. A. (2017). Hukum Bisnis: Dilengkapi Dengan Kajian Hukum Bisnis Syariah. Bandung: PT Refika Aditama.

Undang-undang (UU) No. 8 Tahun 1999. (2018, Mei 30). Diambil kembali dari Badan Standarisasi Nasional https://jdih.bsn.go.id/produk/detail/?id=380\&j $\mathrm{ns}=2$ 